\title{
No More Blood
}

\author{
Kerry Abrams
}

Problems have plagued the ius sanguinis principle - the transmission of citizenship from parent to child - for as long as it has existed. Costica Dumbrava is surely correct that the time has come to ask whether ius sanguinis is still necessary. But the core problem with ius sanguinis, I would argue, is not that it uses the parent-child relationship to determine membership but that it overemphasizes the importance of the genetic tie to this relationship.

The very term ius sanguinis - 'right of blood' - makes the genetic tie the sine qua non of belonging. It is this obsession with genetic purity that has linked ius sanguinis to tribalism, xenophobia, and even genocide. This problem, I believe, is distinct from the very real need to ensure children's access to the same geographic territory and legal system as that of their parents. Rainer Bauböck's proposal for a 'ius filiationis' based on family association rather than genetic ties would excise many of the problems caused by a focus on blood while protecting the parent-child relationship and the stability for children that flows from it.

Let me explain in more detail why I think that retaining recognition of parent-child relationships while abandoning the other features of ius sanguinis is sensible. At first glance, protecting the tying of children's citizenship to that of their parents may appear problematic because of that relationship's historical ties to property ownership. But a closer look shows that children really do deserve different legal treatment than adults, and ius filiationis is one critical way the law can recognise that difference.

Ius sanguinis feels retrograde today because it developed during a time in which relationships between parents and children, as well as relationships between husbands and wives and masters and servants, were much more akin to property-chattel relationships than we understand them to be today. Today's family law was yesterday's law of the household, which set forth entitlements and obligations based on reciprocal legal statuses - parent and child, husband and wife, master and servant, master and apprentice (and sometimes master and slave). Each of these relationships was hierarchical, involving responsibilities on the part of the superior party in the hierarchy 
(father, husband, or master) and obligations of service on the part of the inferior party (child, wife, servant, apprentice, or slave). ${ }^{1}$ The inferior party derived identity from the superior: a wife or a child's nominal citizenship often followed that of the husband or father, but this identity did not confer the same rights enjoyed by the superior party. In early America, for example, male citizens were often entitled to the right to vote, right to contract, and right to own property (in fact, ownership of property was often a prerequisite for voting) but their wives - also technically citizens - were not entitled to any of these rights. Their political participation took the form of providing moral guidance to their husbands and raising virtuous sons who could themselves exercise political power. ${ }^{2}$

Today, we no longer think of citizenship in this way. The rights conferred by citizenship are understood in Western democracies as universal. If, for example, I become a naturalised U.S. citizen, the same neutral voting laws apply to me that apply to any other citizen, regardless of my gender, marital status, race, or national origin. Likewise, laws that imposed derivative citizenship on wives, and even laws that expatriated women upon marriage - both of which used to be widespread - are no longer the norm. In many parts of the world, women are no longer understood as intellectually and financially dependent on their husbands but instead as autonomous adults, capable of making their own economic, moral, and legal decisions, including the decision to consent to citizenship or renounce it. And even more dramatically, we no longer think of servants as deriving legal identity from their masters; instead, workers are free to participate in free, if regulated, labour markets and their citizenship status is independent of their employee status. ${ }^{3}$

The one legal distinction, however, that all countries still maintain in determining the capacity to exercise the rights associated with citizenship is age. Children are generally considered to be incapable of giving legal

\footnotetext{
Halley, J. (2011), 'What is Family Law?: A Genealogy, Part I', Yale Journal of Law \& Humanities 23 (1): 1-109, at 2.

2 Kerber, L. (1980), Women of the Republic: Intellect \& Ideology in Revolutionary America. Chapel Hill: UNC Press.

3 In contrast to the independent citizenship status of workers, employer-sponsored immigration provisions may represent the vestiges of the ancient master-servant status relationship. See Raghunath, R. (2014), 'A Founding Failure of Enforcement: Freedmen, Day Laborers, and the Perils of an Ineffectual State,' C.U.N.Y. L. Rev. 18 (1): 47-91.
} 
consent and in need of legal protection. The particular age at which they become capable of reasoning is contested, but it is incontestable that a newborn cannot care for himself nor meaningfully choose a nationality. In many circumstances, the law provides the protection children need by requiring children's parents to provide for them, care of them, and make decisions for them; in some instances, the state takes on this responsibility (foster care and universal public education are both examples). Children occupy a very different legal space than women or workers, one that makes them vulnerable when their ties to their parents are weakened. Providing children with a citizenship that they can exercise simultaneously with that of at least one of their parents is a critical protection for their wellbeing. We can believe this to be so while simultaneously rejecting the traditional hierarchies of parentchild, husband-wife, and master-slave. The United Kingdom's move away from conceptualizing parent-child relationships as 'custodial', property-like relationships and instead describing them as involving 'parental responsibility' is a good example of this shift. The emphasis has changed from ownership and control to care and protection.

If, then, we still need a form of parent-to-child citizenship transmission, is ius sanguinis as traditionally understood what we need? Scholars, courts, and government agencies often take ius sanguinis literally, as the "rule of blood'. But I think that rigidity is misplaced. Even centuries ago the notion of ius sanguinis meant something distinct from a pure genetic tie. For men, who could never be certain of their child's paternity, transmission 'through blood' often really meant transmission through choice. A man chose to acknowledge his children by marrying, or already being married to, their mother. Children born to unmarried mothers generally took on the citizenship of their mothers, not their fathers, regardless of whether the father was known. The notion of 'blood', then, was complicated by the requirement of marriage for citizenship transmission through the father and the man's unique ability to embrace or repudiate his offspring based on his marital relationship to their mother. Presumably, many children, prior to blood and DNA testing, acquired citizenship iure sanguinis when there was actually no blood tie, sometimes in circumstances where the father was ignorant of this fact and sometimes where he knew full well no blood relationship existed. ${ }^{4}$ Ius sanguinis has always been about more and less than simply blood.

4 Abrams, K. \& K. Piacenti (2014), 'Immigration's Family Values', Va. L. Rev. 100 (4): 629-709, at 660, 663, 692. 
Thus, Bauböck's notion of ius filiationis seems to me both the most appropriate form today for citizenship transmission from parent to child to take, and a more accurate description of what really occurred historically. As I see it, the most challenging obstacle to implementing a ius filiationis system is that birthright citizenship is fixed in time. Courts are not in a position to predict on the date of a child's birth the adult who will ultimately assume parental responsibility for a child, but they can determine who the genetic or marital parent is. Shifting to a ius filiationis system, then, requires a multifaceted response. First, statutes outlining the requirements for citizenship transmission at birth should be amended to identify the intended parents. In most circumstances, the intended parents will be the genetic parents, but in some instances they might be someone else - for example, a non-genetic parent who contracts with a gestational surrogate or the spouse or partner of a genetic parent. Various pieces of evidence, from birth certificates to contracts to court judgments, would be necessary to determine parentage. In cases involving ART, this solution would solve many of the current problems. A genetic tie would be but one piece of evidence in determining citizenship at birth.

In addition to reforming ius sanguinis statutes, however, I believe we must also broaden the other available pathways to citizenship outside of birthright citizenship and traditional forms of naturalisation. There could be a deadline - perhaps by a specified birthday - by when a functional parent could request a declaration of citizenship for the child he or she has parented since birth. This alternative means of citizenship transmission should not substitute for birthright citizenship; as Kristin Collins points out, making citizenship determinations using only functional tests would put children at the mercy of officials seeking to deny citizenship and could disadvantage genetic or intentional fathers who may be unable to demonstrate that their care has been substantial enough to be 'functional.' But combined with a robust recognition of genetic and intentional parentage at birth, recognition of functional parentage later on could serve a supplemental purpose, ensuring that children will ultimately have access to citizenship rights in the country in which their functional parents reside. Full recognition of parent-child relationships requires going beyond the moment of birth so that we can recognise the individuals who actually take on parental responsibility. 
It is premature to forsake the recognition of parent-child relationships in citizenship law, not when citizenship is still the mechanism for ensuring that every human being has membership in at least one state and providing access to basic human rights. But it is time that we abandoned the idea that 'blood' is the sole basis of these relationships.

Open Access This chapter is licensed under the terms of the Creative Commons Attribution 4.0 International License (http://creativecommons.org/licenses/by/4.0/), which permits use, sharing, adaptation, distribution and reproduction in any medium or format, as long as you give appropriate credit to the original author(s) and the source, provide a link to the Creative Commons license and indicate if changes were made.

The images or other third party material in this chapter are included in the chapter's Creative Commons license, unless indicated otherwise in a credit line to the material. If material is not included in the chapter's Creative Commons license and your intended use is not permitted by statutory regulation or exceeds the permitted use, you will need to obtain permission directly from the copyright holder.

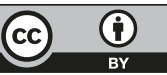

